Niniejsza publikacja jest dostępna na licencji Creative Commons. Uznanie autorstwa-Użycie niekomercyjne-Bez utworów zależnych 3.0 Polska. Pewne prawa zastrzeżone na rzecz autora. Zezwala się na wykorzystanie publikacji zgodnie z licencja - pod warunkiem zachowania niniejszej informacji licencyjnej oraz wskazania autora jako właściciela praw do tekstu. Treść licencji jest dostęna na stronie: http://creativecommons.org/licenses/by-nc-nd/3.0/pl/

Lingwistyka Stosowana 16: 1/2016, 121-134

\author{
Ewa ZAJDLER
}

Uniwersytet Jagielloński

Aneta STAL ${ }^{1}$

Uniwersytet Warszawski

\title{
Ekspozycja na język tonalny a wrażliwość słuchowa
}

\begin{abstract}
:
Exposure to a tonal language and the development of auditory attention

The Chinese language is a tonal language. The four tones of Modern Standard Chinese cause difficulties for non-tonal language users. Learning to recognize foreign speech sounds and to distinguish their phonological features is the process influencing the complex auditory ability. This article presents the pilot study of auditory reactions of Polish-speaking people to learning a tonal language. Pure tone audiometry used in the study provides data of the hearing threshold of subjects exposed and not exposed to the tonal language. Results show change in auditory sensitivity, significant for some frequencies of pure tones stimuli. Due to the small scale of the study it is regarded as a preliminary research.
\end{abstract}

\section{Wstęp}

Chociaż tonalność języka jest cechą suprasegmentalną, to sposób, w jaki wpisuje się w prozodię mowy, zasługuje na szczególną uwagę głownie ze względu na fonologicznie dystynktywny charakter. Obrazowo przedstawia to Künstler w swojej pracy Języki chińskie tak: „W językach omawianego obszaru mamy do czynienia ze strukturą bardziej skomplikowaną: otóż w językach tych - przypomnijmy: określanych jako tonalne każda jednostka sylabiczna (mówimy tu oczywiście w ogromnym uproszczeniu) jest wymawiana w jednym $\mathrm{z}$ tonów, z których składa się system danego języka. Owe tony zajmują w tych językach ,pierwsze piętro”, co stwarza sytuację, w której akcent znajduje się na „drugim piętrze”, a intonacja na „trzecim”.” (zob. M.J. Künstler 2000: 17). Fonemy tonalne języka chińskiego zajmują w dydaktyce fonetyki audytywnej i artykulacyjnej ważne miejsce, bo od umiejętności ich rozróżniania zależą umiejętności językowe w zakresie mowy i jej recepcji oraz ich poprawny i efektywny rozwój.

\footnotetext{
${ }^{1}$ Pani Aneta Stal jest autorką aplikacji sczytującej dane liczbowe z PFD audiometrii tonalnej. Ukończyła z dyplomem licencjackim studia z zakresu fizyki i sinologii na UW oraz z dyplomem magisterskim studia na Wydziale Matematyki, Informatyki i Mechaniki UW.

${ }^{2}$ Badania przeprowadzono na Wydziale Orientalistycznym UW; sfinansowane były z funduszu badań statutowych jednostki, za co autorka wyraża podziękowanie.
} 


\section{Sygnał mowy}

Zważywszy na różnice częstotliwości, w których realizowany jest sygnał mowy w różnych językach, potencjał słyszenia nie przekłada się na taką samą wrażliwość dla wszystkich częstotliwości dźwięku. Skoro poziom słuchu jest mierzalny subiektywnie i obiektywnie, i zależy od budowy i funkcjonowania narządu słuchu, nie można mówić o poprawie słuchu w wyniku wzmożonej pracy nad nim. A jednak ekspozycja dorosłych na język tonalny i konieczność nauczenia się słyszenia i realizacji dźwięków (odbiegających od dotąd znanych częstotliwości i przebiegów) każe nam przyjrzeć się bliżej procesom słyszenia i rozróżniania dźwięków.

Tonalność języka chińskiego jest wyzwaniem dla użytkowników języków nietonalnych uczących się chińskiego w wieku dorosłym. „Słownik języka polskiego” podaje następujące znaczenie wyrazu ton w kontekście języka i komunikacji: „1. dźwięk wywołany przez drgania akustyczne o tej samej częstotliwości (...). 2. miara odległości pomiędzy dźwiękami skali (...). 3. jakość brzmienia głosu lub instrumentu (...). 4. pot. styl tekstu pisanego, mówionego, wyrażający uczucia mówiącego” (E. Sobol 2006: 1043). „Encyklopedia językoznawstwa ogólnego” definiuje ton w kontekście języka następująco: „1. Тyp akcentu, którego istotą są zmiany wysokości brzmienia sylaby. Przeciwstawia się akcentowi dynamicznemu, polegającemu na sile artykulacji. (...) 2. Synonim intonacji” (K. Polański 2003: 605).

W niniejszym rozważaniu tylko pierwsze dwie definicje nawiązują do akustycznej materii mowy, jedna - do generowania dźwięku, druga - do różnicy między dźwiękami. Ton rozumiany jako fonem tonalny w języku chińskim łączy w sobie zbiór cech segmentalnych i suprasegmentalnych. Cechę segmentalną fonemu tonalnego stanowi ten dźwięk sylaby chińskiej, który posiada f0 realizowane w czasie. Obrazowo mówimy, że to samogłoska w sylabie jest nośnikiem tonu. Na wymiar suprasegmentalny składa się zmienna częstotliwość odpowiadająca za infleksję i diapazon danego tonu (zob. E. Zajdler 2010: 275). Cechy te czynią zatem ton w języku chińskim bliższym pojęciu tonu jako różnicy między punktami na skali dźwięków niż tonu rozumianego akustycznie jako drgania. Chociaż w językach tonalnych częstotliwości tonu i rozpiętość rejestru są względne i mają cechy osobnicze, to zakres częstotliwości dla przebiegu poszczególych tonów, podobnie jak głosek, ma swoje uśrednione wartości f0. O ile dla muzyki istotna jest bezwzględna wartość częstotliwości danego tonu, o tyle dla języków tonalnych ważna jest względna częstotliwość w danym rejestrze.

To f0 wyznacza wysokość dźwięku. Dolny zakres widma mowy (100-350 Hz) zawiera aż 50\% energii akustycznej mowy. Mimo że dla języka polskiego istotne jest pasmo100-2300 Hz, to częstotliwość powyżej $350 \mathrm{~Hz}$, przy 50\% energii akustycznej, gwarantuje w pełni jej zrozumienie, gdyż daje 98\% wyrazistości mowy (E. Hojan/ E. Skrodzka 2005: 104-105). Rozkład akustyczny części składowych mowy oprócz częstotliwości podstawowych pokazuje rozkład energii akustycznej wyrażającej się przez natężenie dźwięku (optymalny próg słyszenia to 0-30 dB) (zob. źródło internetowe [1]). Wyraźnie widać, jak dużą energię przejmują samogłoski. Można domniemywać, że przesunięcie poziomu zrozumiałości mowy z niskich częstotliwości w języku polskim na wyższe wiąże się z wysoką frekwencją zbitek spółgłoskowych, które rekompensują utratę energii w niskim rejestrze. 


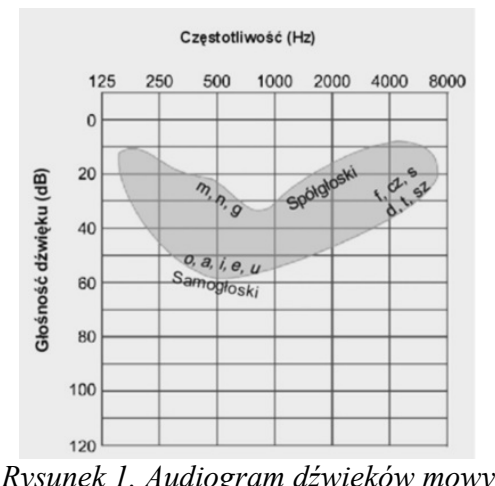

Zakres częstotliwości podstawowej fonacji - najczęściej w 1/3 dolnego zakresu częstotliwości głosu - to przedział, w którym głos w czasie mowy przesuwa się w rejestrze ku górze lub dołowi od 4 do 6 półtonów, oscylując wokół średniej wartości maksimum spektralnego. U mężczyzn to zakres od $a(220 \mathrm{~Hz})$ do $e(330 \mathrm{~Hz})$, u dzieci i kobiet od $a$ $(220 \mathrm{~Hz})$ do $e^{l}(660 \mathrm{~Hz})$ (zob. źródło internetowe [2] str. 20). Dla zobrazowania rozpiętości częstotliwości podstawowych w różnych językach dla głosów żeńskich i męskich podano w tabeli wartości minimalne i maksymalne f0 trzech samogłosek. Przy czym dla języka chińskiego oddzielnie podano wartości skrajne f0 danej samogłoski, a oddzielnie wartości początkowe i końcowe f0 samogłoski w danym tonie (D.H. Whalen / A.G. Levitt 1995: 351-353 $3^{3}$.

\begin{tabular}{|c|c|c|c|c|c|c|}
\hline \multicolumn{2}{|c|}{$[\mathrm{u}]$} & \multicolumn{2}{|c|}{ [i] } & \multicolumn{2}{|c|}{ [o] } & \\
\hline głos żeński & głos męski & głos żeński & głos męski & głos żeński & głos męski & \\
\hline $\mathrm{min} . / \max$. & $\mathrm{min} . / \max$. & $\mathrm{min} . / \max$. & $\mathrm{min} . / \max$. & min. $/ \max$. & min./ max. & \\
\hline $172 \mathrm{~Hz} / 335 \mathrm{~Hz}$ & $90 \mathrm{~Hz} / 206 \mathrm{~Hz}$ & $169 \mathrm{~Hz} / 312 \mathrm{~Hz}$ & $89 \mathrm{~Hz} / 197 \mathrm{~Hz}$ & $171 \mathrm{~Hz} / 302 \mathrm{~Hz}$ & $83 \mathrm{~Hz} / 175 \mathrm{~Hz}$ & chiński \\
\hline $185 \mathrm{~Hz} / 308 \mathrm{~Hz}$ & $116 \mathrm{~Hz} / 143 \mathrm{~Hz}$ & $189 \mathrm{~Hz} / 309 \mathrm{~Hz}$ & $118 \mathrm{~Hz} / 141 \mathrm{~Hz}$ & $194 \mathrm{~Hz} / 288 \mathrm{~Hz}$ & $107 \mathrm{~Hz} / 136 \mathrm{~Hz}$ & wietnamski \\
\hline $175 \mathrm{~Hz} / 323 \mathrm{~Hz}$ & $93 \mathrm{~Hz} / 208 \mathrm{~Hz}$ & $174 \mathrm{~Hz} / 320 \mathrm{~Hz}$ & $93 \mathrm{~Hz} / 206 \mathrm{~Hz}$ & $175 \mathrm{~Hz} / 298 \mathrm{~Hz}$ & $90 \mathrm{~Hz} / 188 \mathrm{~Hz}$ & angielski \\
\hline$-219 \mathrm{~Hz}$ & $95 \mathrm{~Hz} / 140 \mathrm{~Hz}$ & $184 \mathrm{~Hz} / 222 \mathrm{~Hz}$ & $90 \mathrm{~Hz} / 138 \mathrm{~Hz}$ & $167 \mathrm{~Hz} / 210 \mathrm{~Hz}$ & $82 \mathrm{~Hz} / 129 \mathrm{~Hz}$ & niemiecki \\
\hline $243 \mathrm{~Hz} / 300 \mathrm{~Hz}$ & $134 \mathrm{~Hz} / 198 \mathrm{~Hz}$ & $235 \mathrm{~Hz} / 289 \mathrm{~Hz}$ & $132 \mathrm{~Hz} / 199 \mathrm{~Hz}$ & $226 \mathrm{~Hz} / 266 \mathrm{~Hz}$ & $124 \mathrm{~Hz} / 185 \mathrm{~Hz}$ & francuski \\
\hline 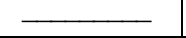 & $153 \mathrm{~Hz}$ & 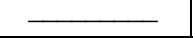 & $153 \mathrm{~Hz}$ & & $150 \mathrm{~Hz}$ & polski \\
\hline $220 \mathrm{~Hz}$ & $122 \mathrm{~Hz}$ & $212 \mathrm{~Hz}$ & $120 \mathrm{~Hz}$ & $182 \mathrm{~Hz}$ & $104 \mathrm{~Hz}$ & duński \\
\hline $222 \mathrm{~Hz}$ & $127 \mathrm{~Hz}$ & $218 \mathrm{~Hz}$ & $128 \mathrm{~Hz}$ & $215 \mathrm{~Hz}$ & $124 \mathrm{~Hz}$ & szwedzki \\
\hline
\end{tabular}

Tabela 1. Częstotliwości podstawowe w różnych językach dla glosów żeńskich i męskich - wartości minimalne i maksymalne dla wybranych samogłosek

${ }^{3}$ Z danych prezentowanych w publikacji D.H. Whalen i A.G. Levitt (1995: 351-353, 357) wybrano tutaj skrajne wartości częstotliwości. Jednak praca ta przywołuje wartości f0 z bardzo wielu publikacji zaznaczając, że reprezentatywność podanych wartości jest względna tak z powodu liczby uczestników (od 1 osoby do 33; najczęściej kilka osób) cytowanych badań, jak i różnorodności kontekstów samogłosek, których częstotliwość podstawową mierzono. Stwierdzono jednak brak statystycznie istotnych różnic wartości f0 dla reprezentowanych języków. 


\begin{tabular}{|c|c|c|c|c|c|c|}
\hline \multicolumn{2}{|c|}{$[\mathrm{u}]$} & \multicolumn{2}{c|}{$[\mathrm{i}]$} & \multicolumn{2}{c|}{$[\mathrm{o}]$} & \\
\hline głos żeński & głos męski & głos żeński & głos męski & głos żeński & głos męski & \\
\hline $307 \mathrm{~Hz}$ & $181 \mathrm{~Hz}$ & $297 \mathrm{~Hz}$ & $175 \mathrm{~Hz}$ & $276 \mathrm{~Hz}$ & $154 \mathrm{~Hz}$ & chiński T1 $^{-}$ \\
\hline $209 \div 289 \mathrm{~Hz}$ & $117 \div 168 \mathrm{~Hz}$ & $205 \div 265 \mathrm{~Hz}$ & $118 \div 167 \mathrm{~Hz}$ & $198 \div 255 \mathrm{~Hz}$ & $111 \div 151 \mathrm{~Hz}$ & chínski T2' \\
\hline $218 \div 172 \mathrm{~Hz}$ & $112 \div 90 \mathrm{~Hz}$ & $219 \div 169 \mathrm{~Hz}$ & $113 \div 89 \mathrm{~Hz}$ & $227 \div 171 \mathrm{~Hz}$ & $108 \div 83 \mathrm{~Hz}$ & chiński T3` \\
\hline $335 \div 184 \mathrm{~Hz}$ & $206 \div 105 \mathrm{~Hz}$ & $312 \div 180 \mathrm{~Hz}$ & $197 \div 97 \mathrm{~Hz}$ & $302 \div 187 \mathrm{~Hz}$ & $175 \div 97 \mathrm{~Hz}$ & chíński T4 \\
\hline
\end{tabular}

Tabela 2. Wartości początkowe i końcowe fo samogloski w tonach języka chińskiego (T1, T2, T3, T4)

\begin{tabular}{|c|cccc|}
\hline & $\mathrm{T}^{-}$ & $\mathrm{T}^{\prime}$ & $\mathrm{T}^{\prime}$ & $\mathrm{T}$ \\
\hline$[\mathrm{i}]$ & $259-257-258$ & $182-162-255$ & $192-142-212$ & $294-227-130$ \\
{$[\mathrm{u}]$} & $291-290-290$ & $186-170-249$ & $197-163-208$ & $334-246-153$ \\
{$[\mathrm{a}]$} & $245-243-244$ & $188-175-243$ & $190-150-202$ & $287-225-154$ \\
{$[\mathrm{ai}]$} & $269-266-267$ & $166-153-245$ & $184-137-201$ & $305-196-145$ \\
{$[\mathrm{ei}]$} & $273-271-275$ & $182-153-246$ & $180-155-214$ & $307-231-142$ \\
{$[\mathrm{ao}]$} & $267-268-267$ & $165-159-250$ & $183-153-211$ & $300-232-141$ \\
{$[\mathrm{ou}]$} & $258-260-255$ & $173-159-241$ & $189-153-211$ & $327-213-143$ \\
\hline
\end{tabular}

Tabela 3. Wartości poczatkowe, środkowe i końcowe fo samogłoski w tonach języka chińskiego

(T1, T2, T3, T4). Guo Junhong et al. (2010: 83)

Spółgłoski, szczególnie bezdźwięczne, realizowane są w wyższym rejestrze, stąd w językach europejskich zrozumiałość mowy względem pasma częstotliwości szacuje się na $1-5 \mathrm{kHz}$.

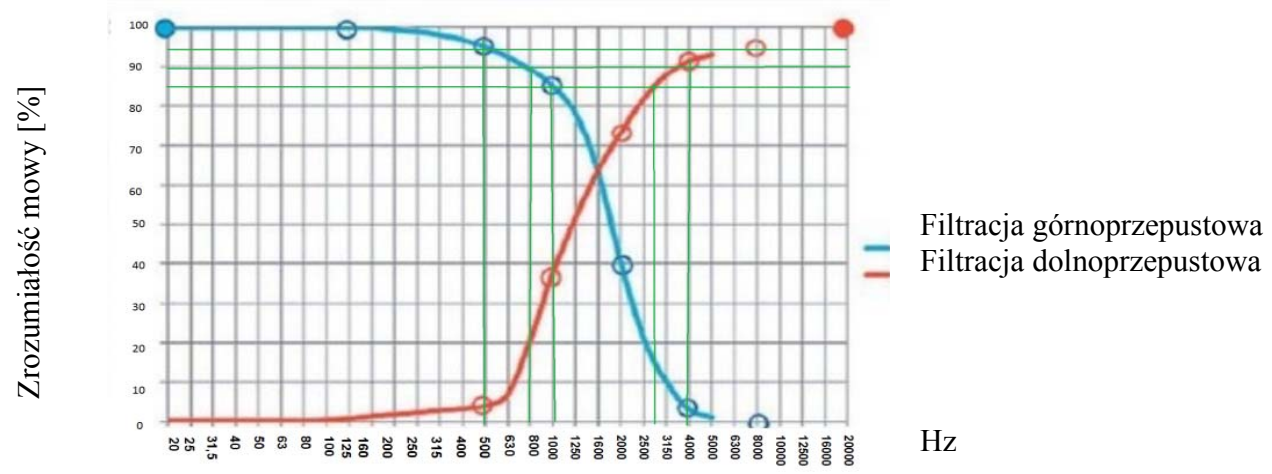

Rysunek 2. Wplyw filtracji górno- i dolnoprzepustowej pasma mowy ludzkiej na zrozumiałość

Przez odfiltrowane pasmo sygnału mowy (filtr górnoprzepustowy) dla kolejnych wartości częstotliwości uzyskano odpowiednio: 100\% zrozumiałości mowy przy częstotliwościach powyżej $100 \mathrm{~Hz}, 95 \%$ - powyżej $500 \mathrm{~Hz}$ i wciąż zadawalającą wartość $85 \%$ powyżej $1 \mathrm{kHz}$. Dalsze odcinanie częstotliwości wpływało na wyraźny spadek poziomu zrozumiałości mowy. Filtracja dolnoprzepustowa, odcinająca wysokie rejestry, wskazuje $4 \mathrm{kHz}$ jako częstotliwość konieczną dla zrozumiałości mowy w więcej niż $90 \%$. Określa się w ten sposób konieczny zakres częstotliwości mowy jako 1-4 kHz (zob. źródło internetowe [3]). Pamiętać należy, że dla poszczególnych języków występują pewne 
różnice eksploatowanych częstotliwości. Guo Junhong et al. (2010: 80) twierdzą, że f0 przebiegu tonów w języku chińskim lokuje się poniżej $300 \mathrm{~Hz}$. Badania w kontekście przystosowania częstotliwości głosu do odbioru przez osoby chińskojęzyczne z poważnym uszkodzeniem słuchu wykazują, że korzystniej dla zachowania informacji wypada filtrowanie dolnoprzepustowe przy częstotliwości granicznej $650 \mathrm{~Hz}$, a nawet $500 \mathrm{~Hz}$, niż filtrowanie górnoprzepustowe.

\section{Cel badania}

Wiek rozpoczęcia nauki szkolnej określa się jako umowną granicę kształtowania się słuchu fonematycznego. Proces uczenia się różnicowania dźwięków w zakresie tonalności przez dorosłych jest sprzężony z nauką produkcji tonów i oceną ich poprawności. Nie jest to tylko jednowymiarowy proces decyzyjny. Bez wątpienia za kluczową należy uznać percepcję dźwięku, czyli możliwości zmysłu słuchu. Postawiono zatem pytanie, jaka jest relacja między słuchem osoby dorosłej (bez ubytku słuchu) i ostrością słyszenia (wrażliwością słuchu) po intensywnej ekspozycji na język tonalny. Za intensywny kontakt z językiem uważa się tu naukę języka chińskiego w mowie (recepcja i produkcja) i w piśmie. Celem badania jest porównanie progu słyszenia w audiometrii tonalnej (częstotliwości standardowe $150-8000 \mathrm{~Hz}$ ) przed rozpoczęciem nauki i na dwóch etapach zaawansowania. Istotny statystycznie wynik sugerowałby zmianę wrażliwości słuchu na określone częstotliwości.

\section{Opis badania}

Wykonano dwukrotny pomiar progu słyszenia w audiometrii tonalnej osób polskojęzycznych: przed rozpoczęciem uczenia się języka chińskiego i po siedmiu miesiącach kursu języka (ok. $400 \mathrm{~h}$ po $45 \mathrm{~min}$.). Pomiarami objęto 27 osób rozpoczynających intensywną naukę języka chińskiego. Ponieważ kilkanaście osób nie ukończyło kursu na oczekiwanym poziomie, uznano, że nie spełniały one kryterium intensywności ekspozycji na bodźce językowe. Zgodnie z założeniem samego kursu, za miarę spełnienia kryterium przyjęto osiągnięcie poziomu umiejętności zbliżonego do A1+/A2. Dlatego pomiar dwukrotny w tej grupie uczestników dotyczy 14 badanych. Zbadano także niewielką, dziewięcioosobową grupę studentów z zaawansowaną znajomością języka chińskiego na poziomie B2+/C1. Wyniki pomiarów stały się podstawą do analizy.

Przebieg krzywej progu słyszenia ustalono za pomocą audiometrii tonalnej - pomiaru reakcji na bodźcowanie tonami czystymi na jedenastu różnych częstotliwościach $(125 \mathrm{~Hz}, 250 \mathrm{~Hz}, 500 \mathrm{~Hz}, 750 \mathrm{~Hz}, 1000 \mathrm{~Hz}, 1500 \mathrm{~Hz}, 2000 \mathrm{~Hz}, 3000 \mathrm{~Hz}, 4000 \mathrm{~Hz}, 6000$ $\mathrm{Hz}, 8000 \mathrm{~Hz}$ ). Wyniki to subiektywna odpowiedź na percepcję najcichszego dźwięku (wartości podane $\mathrm{w} \mathrm{dB}$ ).

Uczestnicy badania:

Grupa 1. poddana pomiarom dwa razy (próba zależna).

Grupa 2. i Grupa 3. (pomiary niezależne).

Uzyskane dane progu słyszenia:

1) Grupa 1. (14 osób); badanie pierwsze (lewy kanał, prawy kanał).

2) Grupa 1. (14 osób); badanie drugie (poziom A1+/A2) (lewy kanał, prawy kanał). 
3) Grupa 2. (27 osób); badanie bez ekspozycji na chiński (lewy kanał, prawy kanał).

4) Grupa 3. (9 osób); badanie po długotrwałym uczeniu się języka chińskiego (poziom B2+/C1) (lewy kanał, prawy kanał).

\section{Analiza wyników}

(1) Badanie 1

W celu sprawdzenia, czy próg słyszenia u osób polskojęzycznych po siedmio-miesięcznej intensywnej ekspozycji na język tonalny różni się od progu słyszenia osób nieznających języka chińskiego, porównano wyniki audiometrii tonalnej prawego (Tabela 4.; Wykres 1.) i lewego (Tabela 5.; Wykres 3.) kanału słuchowego. Dla weryfikacji statystycznej istotności pomiarów zastosowano test Wilcoxona. W wykresach kolumnowych (2. i 4.) poniżej przedstawiono wyniki z przeprowadzonych porównań.

\begin{tabular}{|c|c|c|c|c|c|c|}
\hline Ucho & Częstotliwość & Badanie & Średnia & $\begin{array}{c}\text { Odchylenie } \\
\text { standardowe }\end{array}$ & $\begin{array}{l}\text { Wynik te- } \\
\text { stu Z }\end{array}$ & $\begin{array}{c}\text { Poziom } \\
\text { istotności }\end{array}$ \\
\hline \multirow{22}{*}{ Prawe } & \multirow{2}{*}{$125 \mathrm{~Hz}$} & Przed nauka języka & 9,29 & 5,50 & \multirow{2}{*}{1,28} & \multirow{2}{*}{0,201} \\
\hline & & Po ok. 400h zajęć & 6,43 & 5,35 & & \\
\hline & \multirow{2}{*}{$250 \mathrm{~Hz}$} & Przed nauką języka & 10,00 & 6,20 & \multirow{2}{*}{2,18} & \multirow{2}{*}{0,029} \\
\hline & & Po ok. 400h zajęć & 6,07 & 4,01 & & \\
\hline & \multirow{2}{*}{$500 \mathrm{~Hz}$} & Przed nauką języka & 8,93 & 6,56 & \multirow{2}{*}{1,73} & \multirow{2}{*}{0,084} \\
\hline & & Po ok. 400h zajęć & 6,07 & 3,5 & & \\
\hline & \multirow{2}{*}{$750 \mathrm{~Hz}$} & Przed nauką języka & 7,14 & 5,79 & \multirow{2}{*}{1,65} & \multirow{2}{*}{0,100} \\
\hline & & Po ok. 400h zajęć & 4,64 & 3,65 & & \\
\hline & \multirow{2}{*}{$1 \mathrm{kHz}$} & Przed nauką języka & 5,36 & 4,14 & \multirow{2}{*}{2,66} & \multirow{2}{*}{0,008} \\
\hline & & Po ok. 400h zajęć & 0,36 & 5,71 & & \\
\hline & \multirow{2}{*}{$1,5 \mathrm{kHz}$} & Przed nauką języka & 4,64 & 4,14 & \multirow{2}{*}{2,17} & \multirow{2}{*}{$\mathbf{0 , 0 3 0}$} \\
\hline & & Po ok. 400h zajęć & 1,43 & 3,06 & & \\
\hline & \multirow{2}{*}{$2 \mathrm{kHz}$} & Przed nauką języka & 3,93 & 5,61 & \multirow{2}{*}{1,73} & \multirow{2}{*}{0,084} \\
\hline & & Po ok. 400h zajęć & 1,43 & 4,13 & & \\
\hline & \multirow{2}{*}{$3 \mathrm{kHz}$} & Przed nauką języka & 1,43 & 4,13 & \multirow{2}{*}{1,51} & \multirow{2}{*}{0,132} \\
\hline & & Po ok. 400h zajęć & $-0,36$ & 4,14 & & \\
\hline & \multirow{2}{*}{$4 \mathrm{kHz}$} & Przed nauką języka & 0,36 & 4,14 & \multirow{2}{*}{1,04} & \multirow{2}{*}{0,297} \\
\hline & & Po ok. 400h zajęć & $-1,07$ & 5,94 & & \\
\hline & \multirow{2}{*}{$6 \mathrm{kHz}$} & Przed nauką języka & $-3,93$ & 5,94 & \multirow{2}{*}{1,15} & \multirow{2}{*}{0,250} \\
\hline & & Po ok. 400h zajęć & $-6,07$ & 6,84 & & \\
\hline & \multirow{2}{*}{$8 \mathrm{kHz}$} & Przed nauką języka & 1,43 & 8,42 & \multirow{2}{*}{1,62} & \multirow{2}{*}{0,106} \\
\hline & & Po ok. 400h zajęć & $-2,86$ & 5,79 & & \\
\hline
\end{tabular}

Tabela 4. Wyniki audiometrii tonalnej prawego kanalu stuchowego

Analiza testem Wilcoxona wykazała istotne statystycznie różnice. Oznacza to, że dla prawego kanału dla częstotliwości $250 \mathrm{~Hz}, 1 \mathrm{kHz}$ i $1,5 \mathrm{kHz}$ u badanych osób przed nauką języka próg słyszenia przebiegał na wyższym poziomie decybeli niż po intensywnej ekspozycji na język chiński. 


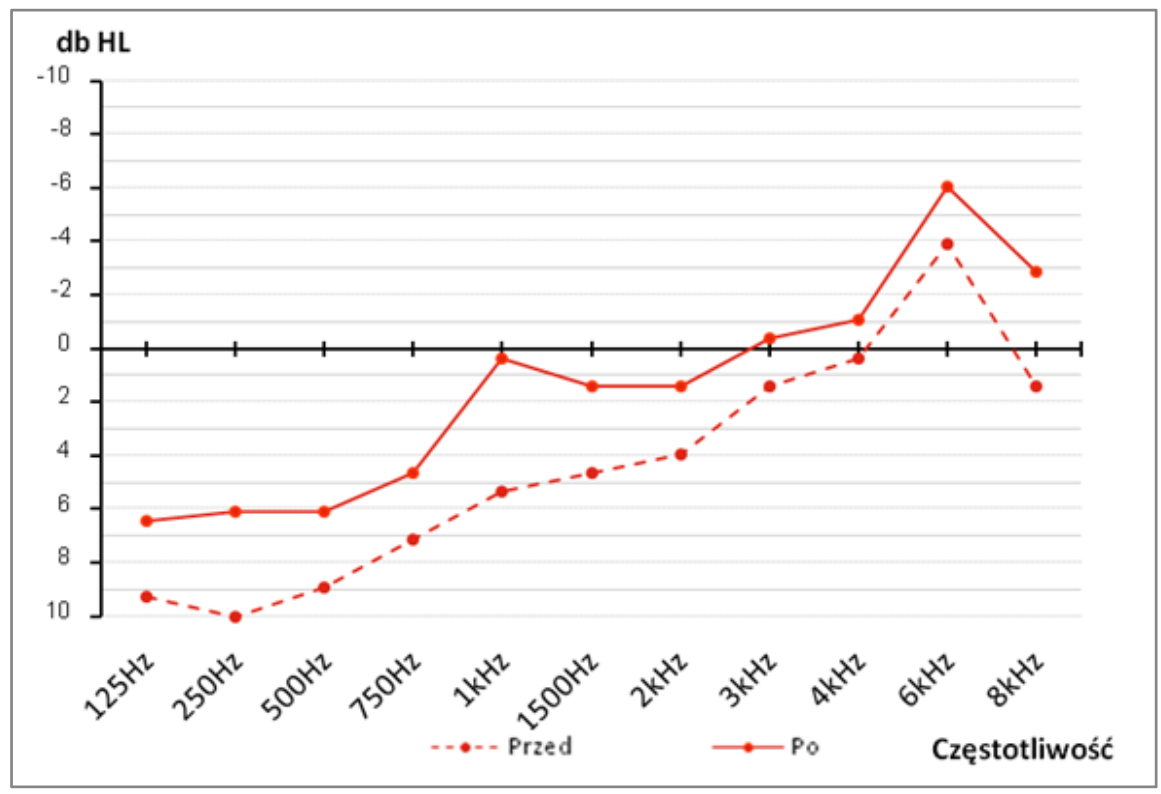

Wykres 1. Wyniki dwukrotnej audiometrii tonalnej prawego kanału słuchowego

Różnica progu słyszenia według średnich wyników dwukrotnego pomiaru audiometrii tonalnej prawego kanału wypadła dla wszystkich częstotliwości dodatnio. Mieści się między 1,43 dB (dla częstotliwości 4kHz) a $5 \mathrm{~dB}$ (dla częstotliwości $1 \mathrm{kHz}$ ). Najwyraźniejsza zmiana progu słyszenia dotyczy dwóch częstotliwości: 1 i $8 \mathrm{kHz}$.

\begin{tabular}{|r|r|r|r|}
\hline & przed & po & $\begin{array}{r}\text { róż- } \\
\text { nica }\end{array}$ \\
\hline $125 \mathrm{~Hz}$ & 9,29 & 6,43 & 2,86 \\
\hline $250 \mathrm{~Hz}$ & 10,00 & 6,07 & 3,93 \\
\hline $500 \mathrm{~Hz}$ & 8,93 & 6,07 & 2,86 \\
\hline $750 \mathrm{kHz}$ & 7,14 & 4,64 & 2,5 \\
\hline $1 \mathrm{kHz}$ & 5,36 & 0,36 & 5,0 \\
\hline $1,5 \mathrm{~Hz}$ & 4,64 & 1,43 & 3,21 \\
\hline $2 \mathrm{kHz}$ & 3,93 & 1,43 & 2,5 \\
\hline $3 \mathrm{kHz}$ & 1,43 & $-0,36$ & 1,79 \\
\hline $4 \mathrm{kHz}$ & 0,36 & $-1,07$ & 1,43 \\
\hline $6 \mathrm{kHz}$ & $-3,93$ & $-6,07$ & 2,14 \\
\hline $8 \mathrm{kHz}$ & 1,43 & $-2,86$ & 4,29 \\
\hline
\end{tabular}

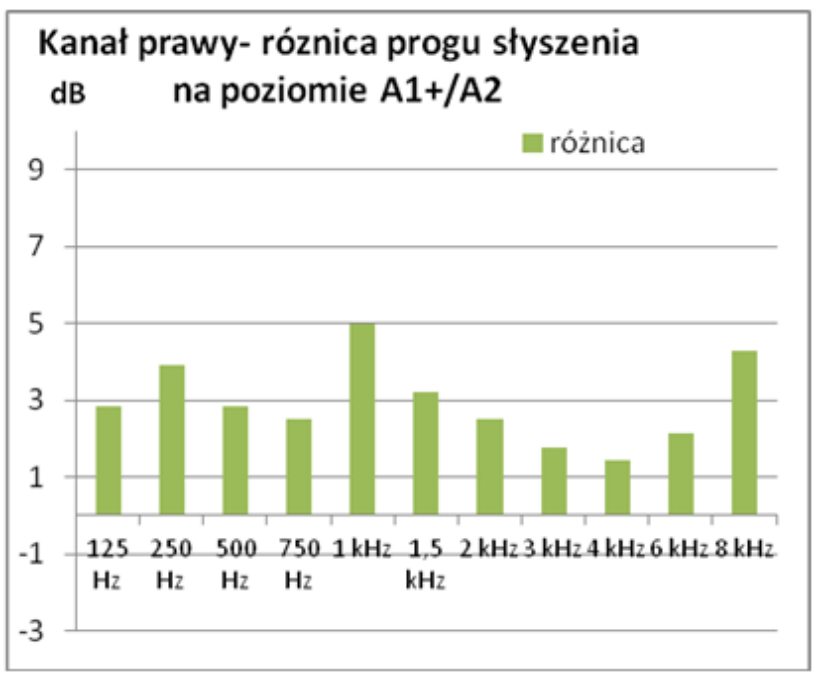

Wykres 2. Różnica progu styszenia 


\begin{tabular}{|c|c|c|c|c|c|c|}
\hline Ucho & Częstotliwość & Badanie & Średnia & $\begin{array}{l}\text { Odchylenie } \\
\text { standardowe }\end{array}$ & $\begin{array}{c}\text { Wynik te- } \\
\text { stu Z }\end{array}$ & $\begin{array}{c}\text { Poziom } \\
\text { istotności }\end{array}$ \\
\hline \multirow{22}{*}{ Lewe } & \multirow{2}{*}{$125 \mathrm{~Hz}$} & Przed nauką języka & 11,07 & 4,46 & \multirow{2}{*}{0,73} & \multirow{2}{*}{0,463} \\
\hline & & Po ok. 400h zajęć & 9,64 & 6,34 & & \\
\hline & \multirow{2}{*}{$250 \mathrm{~Hz}$} & Przed nauką języka & 9,64 & 5,36 & \multirow{2}{*}{0,83} & \multirow{2}{*}{0,405} \\
\hline & & Po ok. 400h zajęć & 8,57 & 5,69 & & \\
\hline & \multirow{2}{*}{$500 \mathrm{~Hz}$} & Przed nauką języka & 9,29 & 6,16 & \multirow{2}{*}{1,67} & \multirow{2}{*}{0,096} \\
\hline & & Po ok. 400h zajeć & 7,50 & 5,46 & & \\
\hline & \multirow{2}{*}{$750 \mathrm{~Hz}$} & Przed nauką języka & 10,00 & 6,20 & \multirow{2}{*}{0,69} & \multirow{2}{*}{0,490} \\
\hline & & Po ok. 400h zajęć & 8,93 & 5,25 & & \\
\hline & \multirow{2}{*}{$1 \mathrm{kHz}$} & Przed nauką języka & 8,21 & 5,41 & \multirow{2}{*}{1,90} & \multirow{2}{*}{0,058} \\
\hline & & Po ok. 400h zajęć & 6,07 & 4,87 & & \\
\hline & \multirow{2}{*}{$1,5 \mathrm{kHz}$} & Przed nauką języka & 7,14 & 6,42 & \multirow{2}{*}{2,35} & \multirow{2}{*}{0,019} \\
\hline & & Po ok. 400h zajęć & 3,57 & 4,13 & & \\
\hline & \multirow{2}{*}{$2 \mathrm{kHz}$} & Przed nauką języka & 9,29 & 7,03 & \multirow{2}{*}{3,16} & \multirow{2}{*}{0,002} \\
\hline & & Po ok. 400h zajęć & 5,71 & 7,30 & & \\
\hline & \multirow{2}{*}{$3 \mathrm{kHz}$} & Przed nauką języka & 5,36 & 6,03 & \multirow{2}{*}{1,81} & \multirow{2}{*}{0,070} \\
\hline & & Po ok. 400h zajęć & 2,86 & 6,11 & & \\
\hline & \multirow{2}{*}{$4 \mathrm{kHz}$} & Przed nauką języka & 2,86 & 8,48 & \multirow{2}{*}{0,71} & \multirow{2}{*}{0,477} \\
\hline & & Po ok. 400h zajęć & 1,79 & 6,39 & & \\
\hline & \multirow{2}{*}{$6 \mathrm{kHz}$} & Przed nauką języka & 0,71 & 6,75 & \multirow{2}{*}{2,99} & \multirow{2}{*}{$\mathbf{0 , 0 0 3}$} \\
\hline & & Po ok. 400h zajęć & $-6,79$ & 3,72 & & \\
\hline & \multirow{2}{*}{$8 \mathrm{kHz}$} & Przed nauką języka & 1,07 & 4,46 & \multirow{2}{*}{2,45} & \multirow{2}{*}{0,014} \\
\hline & & Po ok. 400h zajęć & $-3,21$ & 6,39 & & \\
\hline
\end{tabular}

Tabela 5. Wyniki audiometrii tonalnej lewego kanatu stuchowego

Analiza testem Wilcoxona wykazała istotne statystycznie różnice. Oznacza to, że dla lewego kanału dla częstotliwości $1,5 \mathrm{kHz}, 2 \mathrm{kHz}, 6 \mathrm{kHz}$ i $8 \mathrm{kHz}$ u badanych osób przed nauką języka próg słyszenia przebiegał na wyższym poziomie decybeli niż po intensywnej ekspozycji na język chiński.

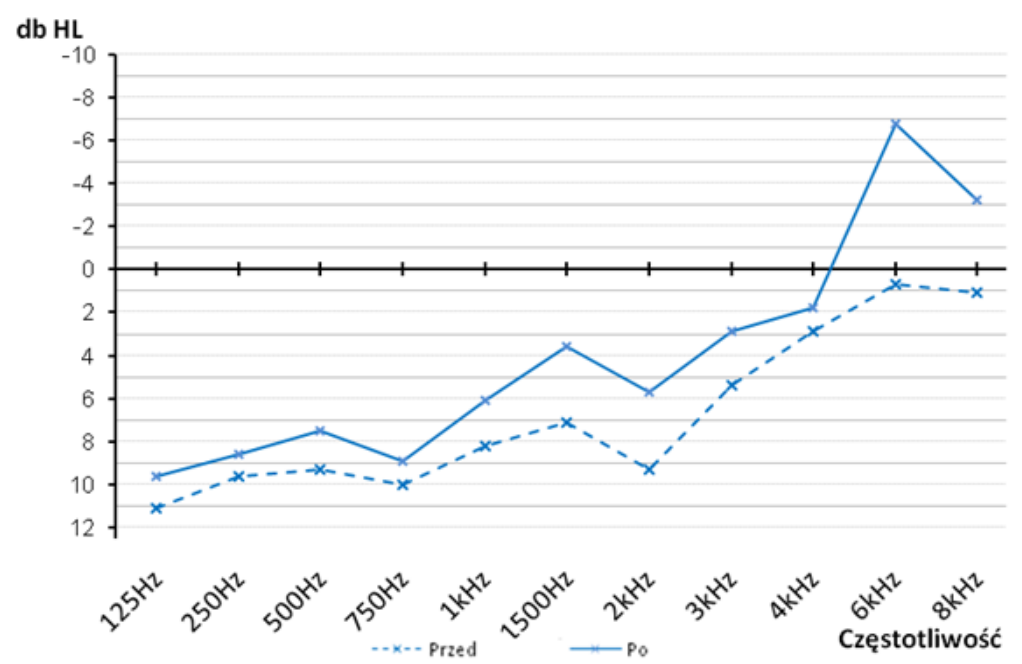

Wykres 3. Wyniki dwukrotnej audiometrii tonalnej lewego kanatu stuchowego 
Różnica progu słyszenia według średnich wyników dwukrotnego pomiaru audiometrii tonalnej lewego kanału wypadła dla wszystkich częstotliwości dodatnio. Mieści się między $1,07 \mathrm{~dB}$ (dla częstotliwości $250 \mathrm{~Hz}, 750 \mathrm{~Hz}$ i $4 \mathrm{kHz}$ ) a 7,5 dB (dla częstotliwości 6 $\mathrm{kHz}$ ). Najwyraźniejsza zmiana progu słyszenia dotyczy dwóch najwyższych sprawdzanych częstotliwości: 6 i $8 \mathrm{kHz}$.

\begin{tabular}{|r|r|r|r|}
\hline & przed & po & różnica \\
\hline $125 \mathrm{~Hz}$ & 11,07 & 9,64 & 1,43 \\
\hline $250 \mathrm{~Hz}$ & 9,64 & 8,57 & 1,07 \\
\hline $500 \mathrm{~Hz}$ & 9,29 & 7,50 & 1,79 \\
\hline $750 \mathrm{~Hz}$ & 10,00 & 8,93 & 1,07 \\
\hline $1 \mathrm{kHz}$ & 8,21 & 6,07 & 2,14 \\
\hline $1,5 \mathrm{~Hz}$ & 7,14 & 3,57 & 3,57 \\
\hline $2 \mathrm{kHz}$ & 9,29 & 5,71 & 3,58 \\
\hline $3 \mathrm{kHz}$ & 5,36 & 2,86 & 2,5 \\
\hline $4 \mathrm{kHz}$ & 2,86 & 1,79 & 1,07 \\
\hline $6 \mathrm{kHz}$ & 0,71 & $-6,79$ & 7,5 \\
\hline $8 \mathrm{kHz}$ & 1,07 & $-3,21$ & 4,28 \\
\hline
\end{tabular}

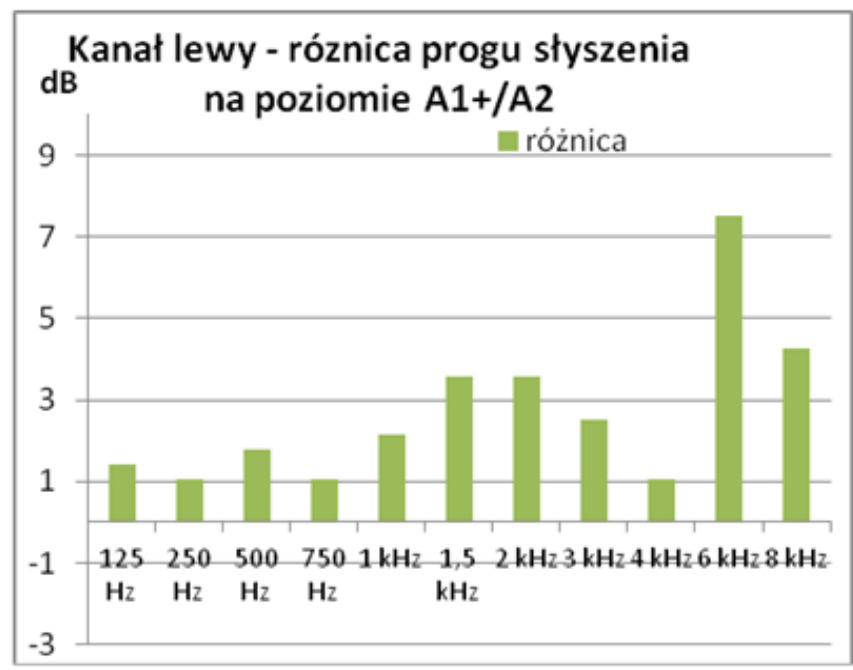

Wykres 4. Różnica progu styszenia

(2) Badanie 2

W celu sprawdzenia, czy próg słyszenia u osób polskojęzycznych po kilkuletniej ekspozycji na język tonalny (poziom B2+/C1) różni się od progu słyszenia osób nie znających języka chińskiego, wykonano pomiary dla dwóch grup niezależnych. Porównano wyniki audiometrii tonalnej prawego (Tabela 6.; Wykres 5.) i lewego (Tabela 7.; Wykres 7.) kanału słuchowego. Dla weryfikacji statystycznej istotności pomiarów zastosowano test U Manna-Whitneya. W wykresach kolumnowych (6. i 8.) poniżej przedstawiono wyniki z przeprowadzonych porównań

\begin{tabular}{|c|c|c|c|c|c|c|}
\hline Ucho & Częstotliwość & Grupa & Średnia & $\begin{array}{l}\text { Odchylenie } \\
\text { standardowe }\end{array}$ & $\begin{array}{c}\text { Wynik testu } \\
\text { Z }\end{array}$ & $\begin{array}{c}\text { Poziom istot- } \\
\text { ności }\end{array}$ \\
\hline \multirow{12}{*}{ Prawe } & \multirow{2}{*}{$125 \mathrm{~Hz}$} & Bez ekspozycji na chiński & 9,26 & 6,31 & \multirow{2}{*}{0,77} & \multirow{2}{*}{0,472} \\
\hline & & Po długotrwałej ekspozycji & 7,22 & 5,65 & & \\
\hline & \multirow{2}{*}{$250 \mathrm{~Hz}$} & Bez ekspozycji na chiński & 8,33 & 6,65 & \multirow{2}{*}{0,72} & \multirow{2}{*}{0,494} \\
\hline & & Po długotrwałej ekspozycji & 6,67 & 4,33 & & \\
\hline & \multirow{2}{*}{$500 \mathrm{~Hz}$} & Bez ekspozycji na chiński & 8,15 & 6,07 & \multirow{2}{*}{0,83} & \multirow{2}{*}{0,428} \\
\hline & & Po długotrwałej ekspozycji & 6,11 & 4,86 & & \\
\hline & \multirow{2}{*}{$750 \mathrm{~Hz}$} & Bez ekspozycji na chiński & 6,48 & 5,85 & \multirow{2}{*}{1,05} & \multirow{2}{*}{0,330} \\
\hline & & Po długotrwałej ekspozycji & 8,89 & 3,33 & & \\
\hline & \multirow{2}{*}{$1 \mathrm{kHz}$} & Bez ekspozycji na chiński & 5,37 & 5,18 & \multirow{2}{*}{0,17} & \multirow{2}{*}{0,886} \\
\hline & & Po długotrwałej ekspozycji & 5,00 & 3,54 & & \\
\hline & \multirow{2}{*}{$1,5 \mathrm{kHz}$} & Bez ekspozycji na chiński & 4,26 & 5,13 & \multirow{2}{*}{0,31} & \multirow{2}{*}{0,774} \\
\hline & & Po długotrwałej ekspozycji & 3,89 & 3,33 & & \\
\hline
\end{tabular}




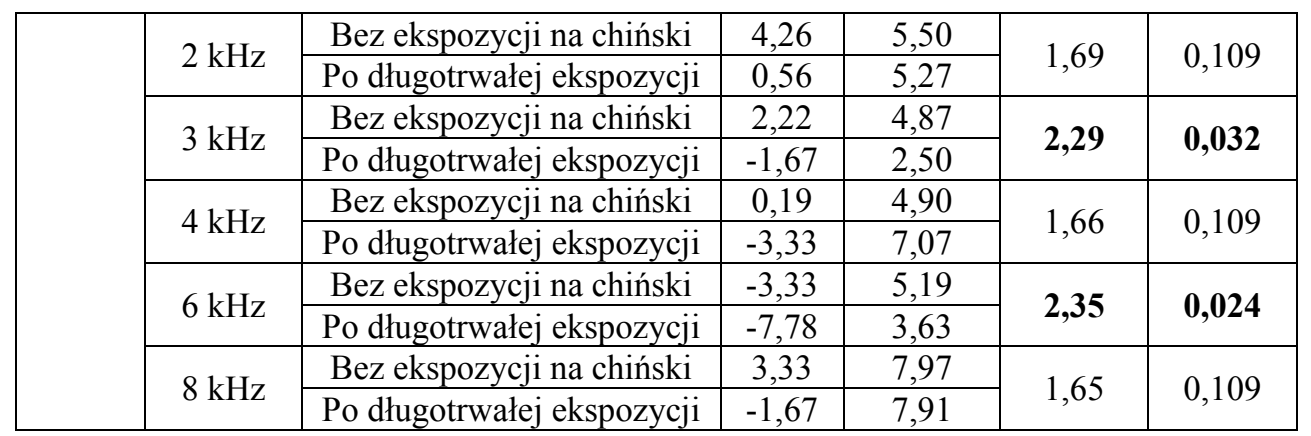

Tabela 6. Wyniki audiometrii tonalnej prawego kanatu stuchowego

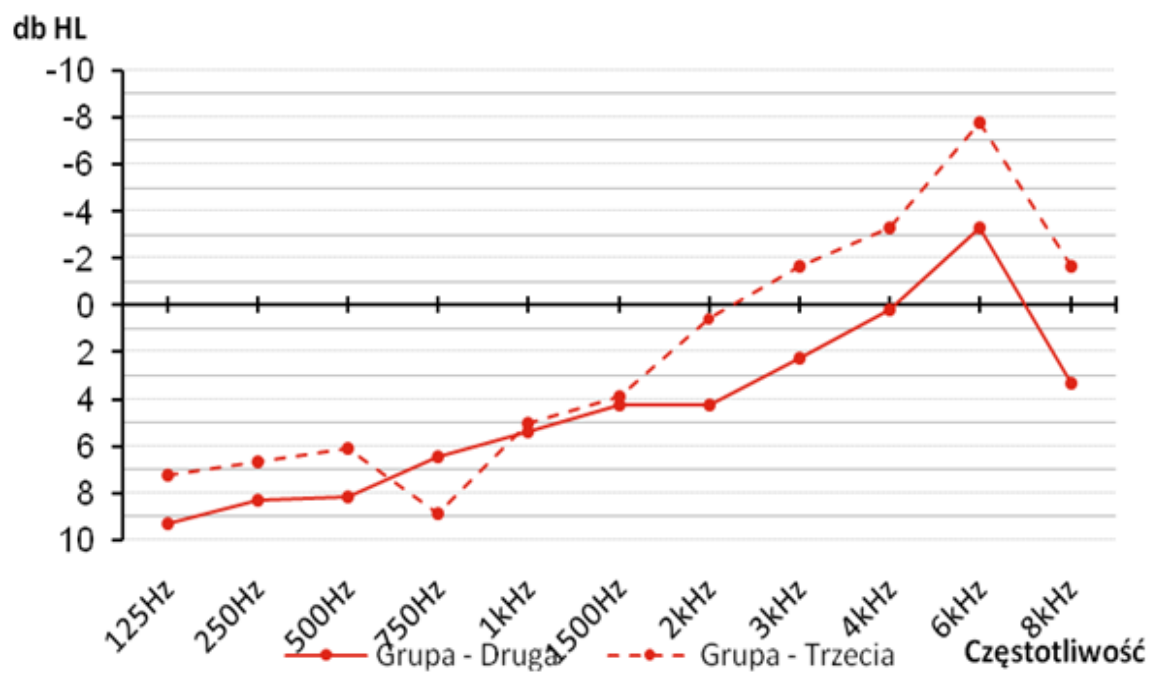

Analiza testem U Manna-Whitneya wykazała istotne statystycznie różnice. Oznacza to, że dla prawego kanału dla częstotliwości $3 \mathrm{kHz}$ i $6 \mathrm{kHz}$ u badanych osób z grupy bez ekspozycji na język chiński próg słyszenia przebiegał na wyższym poziomie decybeli niż u osób po długotrwałej i intensywnej ekspozycji na język chiński.

Wykres 5. Wyniki audiometrii tonalnej prawego kanalu stuchowego grupy 2. i grupy 3.

Różnica progu słyszenia według średnich wyników pomiaru audiometrii tonalnej prawego kanału w dwóch niezależnych grupach (osób bez wystawienia na bodźcowanie językiem chińskim i po długotrwałej i intensywnej ekspozycji na bodźcowanie językiem chińskim) wypadła dla wszystkich częstotliwości dodatnio z wyjątkiem częstotliwości $750 \mathrm{~Hz}$. Mieści się między 0,37 dB (dla częstotliwości $1 \mathrm{kHz}$ i 1,5 kHz) a $5 \mathrm{~dB}$ (dla częstotliwości $8 \mathrm{kHz}$ ). Najwyraźniejsza zmiana progu słyszenia dotyczy dwóch najwyższych sprawdzanych częstotliwości: 6 i $8 \mathrm{kHz}$. 


\begin{tabular}{|c|r|r|c|}
\hline & przed & po & różnica \\
\hline $125 \mathrm{~Hz}$ & 9,26 & 7,22 & 2,04 \\
\hline $250 \mathrm{~Hz}$ & 8,33 & 6,67 & 1,66 \\
\hline $500 \mathrm{~Hz}$ & 8,15 & 6,11 & 2,04 \\
\hline $750 \mathrm{~Hz}$ & 6,48 & 8,89 & $-2,41$ \\
\hline $1 \mathrm{kHz}$ & 5,37 & 5,00 & 0,37 \\
\hline $1,5 \mathrm{~Hz}$ & 4,26 & 3,89 & 0,37 \\
\hline $2 \mathrm{kHz}$ & 4,26 & 0,56 & 3,7 \\
\hline $3 \mathrm{kHz}$ & 2,22 & $-1,67$ & 3,89 \\
\hline $4 \mathrm{kHz}$ & 0,19 & $-3,33$ & 3,52 \\
\hline $6 \mathrm{kHz}$ & $-3,33$ & $-7,78$ & 4,45 \\
\hline $8 \mathrm{kHz}$ & 3,33 & $-1,67$ & 5 \\
\hline
\end{tabular}

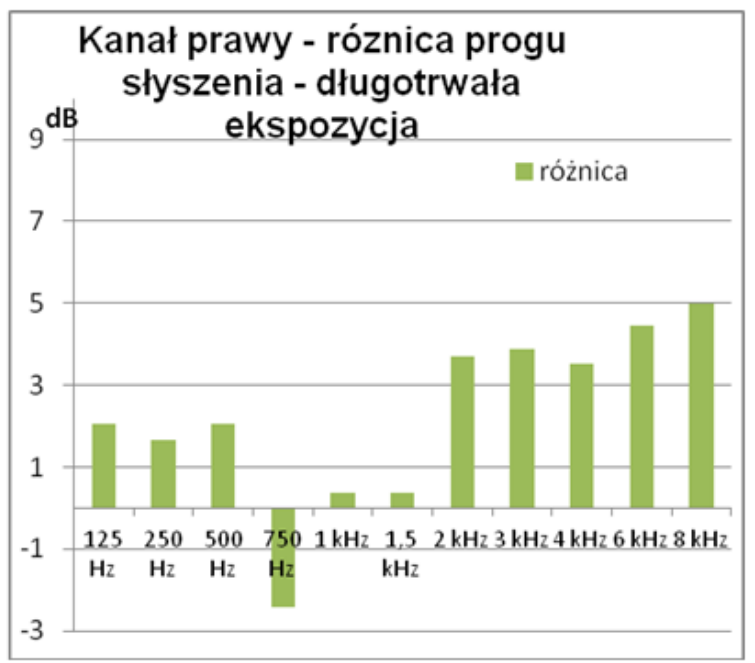

Wykres 6. Różnica progu styszenia

\begin{tabular}{|c|c|c|c|c|c|c|}
\hline Ucho & Częstotliwość & Grupa & Średnia & $\begin{array}{l}\text { Odchylenie } \\
\text { standardowe }\end{array}$ & $\begin{array}{l}\text { Wynik } \\
\text { testu Z }\end{array}$ & $\begin{array}{c}\text { Poziom } \\
\text { istotności }\end{array}$ \\
\hline \multirow{22}{*}{ Lewe } & \multirow{2}{*}{$125 \mathrm{~Hz}$} & Bez ekspozycji na chiński & 10,00 & 5,55 & \multirow{2}{*}{0,84} & \multirow{2}{*}{0,428} \\
\hline & & Po długotrwałej ekspozycji & 8,33 & 5,00 & & \\
\hline & \multirow{2}{*}{$250 \mathrm{~Hz}$} & Bez ekspozycji na chiński & 8,70 & 5,11 & \multirow{2}{*}{0,35} & \multirow{2}{*}{0,747} \\
\hline & & Po długotrwałej ekspozycji & 8,89 & 6,97 & & \\
\hline & \multirow{2}{*}{$500 \mathrm{~Hz}$} & Bez ekspozycji na chiński & 9,26 & 5,83 & \multirow{2}{*}{0,19} & \multirow{2}{*}{0,858} \\
\hline & & Po długotrwałej ekspozycji & 8,89 & 6,01 & & \\
\hline & \multirow{2}{*}{$750 \mathrm{~Hz}$} & Bez ekspozycji na chiński & 9,81 & 5,80 & \multirow{2}{*}{0,44} & \multirow{2}{*}{0,693} \\
\hline & & Po długotrwałej ekspozycji & 10,00 & 8,29 & & \\
\hline & \multirow{2}{*}{$1 \mathrm{kHz}$} & Bez ekspozycji na chiński & 7,59 & 5,26 & \multirow{2}{*}{0,97} & \multirow{2}{*}{0,368} \\
\hline & & Po długotrwałej ekspozycji & 6,11 & 6,01 & & \\
\hline & \multirow{2}{*}{$1,5 \mathrm{kHz}$} & Bez ekspozycji na chiński & 6,48 & 5,85 & \multirow{2}{*}{1,19} & \multirow{2}{*}{0,263} \\
\hline & & Po długotrwałej ekspozycji & 3,33 & 7,07 & & \\
\hline & \multirow{2}{*}{$2 \mathrm{kHz}$} & Bez ekspozycji na chiński & 8,15 & 6,95 & \multirow{2}{*}{1,06} & \multirow{2}{*}{0,312} \\
\hline & & Po długotrwałej ekspozycji & 5,00 & 8,29 & & \\
\hline & \multirow{2}{*}{$3 \mathrm{kHz}$} & Bez ekspozycji na chiński & 4,81 & 6,86 & \multirow{2}{*}{1,45} & \multirow{2}{*}{0,180} \\
\hline & & Po długotrwałej ekspozycji & 1,11 & 5,46 & & \\
\hline & \multirow{2}{*}{$4 \mathrm{kHz}$} & Bez ekspozycji na chiński & 3,15 & 7,61 & \multirow{2}{*}{0,04} & \multirow{2}{*}{0,971} \\
\hline & & Po długotrwałej ekspozycji & 2,22 & 7,12 & & \\
\hline & \multirow{2}{*}{$6 \mathrm{kHz}$} & Bez ekspozycji na chiński & $-0,19$ & 6,72 & \multirow{2}{*}{0,78} & \multirow{2}{*}{0,472} \\
\hline & & Po długotrwałej ekspozycji & $-2,22$ & 6,67 & & \\
\hline & \multirow{2}{*}{$8 \mathrm{kHz}$} & Bez ekspozycji na chiński & 1,11 & 6,70 & \multirow{2}{*}{0,11} & \multirow{2}{*}{0,914} \\
\hline & & Po długotrwałej ekspozycji & 0,56 & 5,83 & & \\
\hline
\end{tabular}

Tabela 7. Wyniki audiometrii tonalnej lewego kanału stuchowego 
Analiza testem U Manna-Whitneya nie wykazała istotnych statystycznie różnic. Oznacza to, że osoby po długotrwałej i intensywnej ekspozycji na język chiński nie różnią się od osób bez terapii pod względem wyników audiometrii tonalnej bodźcowej lewego kanału na jedenastu różnych częstotliwościach.

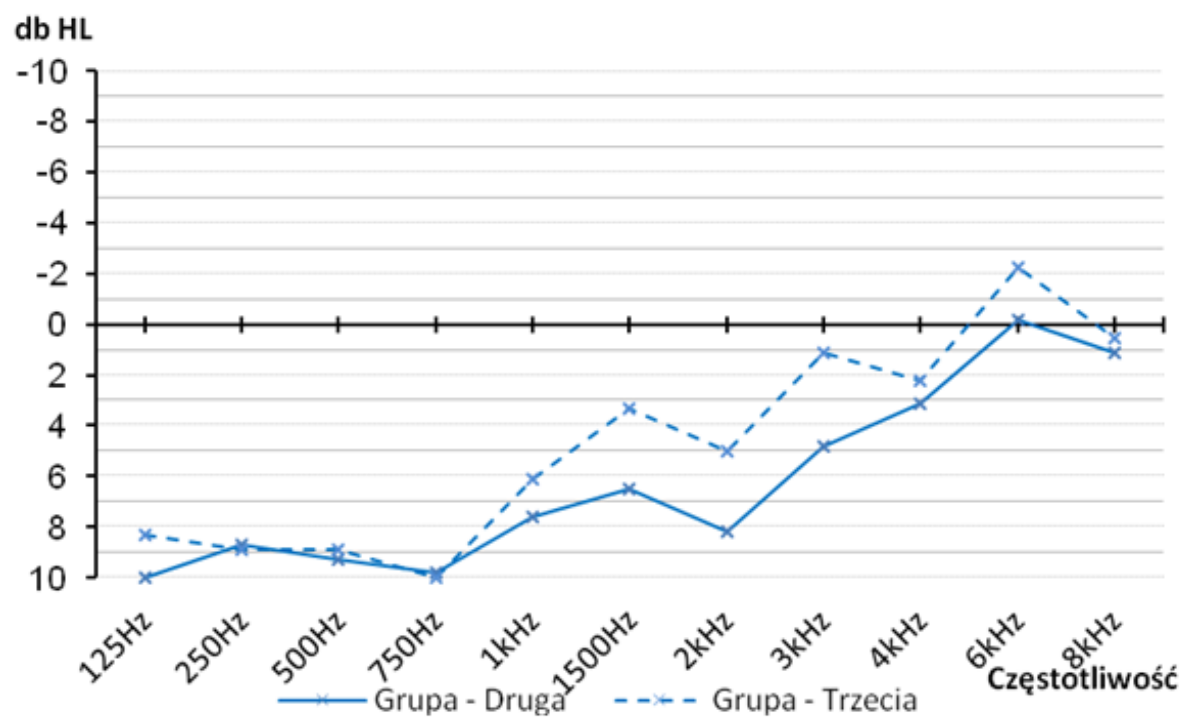

Wykres 7. Wyniki audiometrii tonalnej lewego kanalu stuchowego grupy 2. i grupy 3.

Różnica progu słyszenia według średnich wyników pomiaru audiometrii tonalnej lewego kanału w dwóch niezależnych grupach (Grupy 2. osób bez wystawieniem na bodźcowanie językiem chińskim i Grupy 3. po długotrwałej i intensywnej ekspozycji na bodźcowanie językiem chińskim) wypadła nieznacznie ujemnie dla częstotliwości 250 $\mathrm{Hz}$ i $750 \mathrm{~Hz}$. Wynik dodatni mieści się między $0,37 \mathrm{~dB}$ (dla częstotliwości $500 \mathrm{~Hz}$ ) a $3,70 \mathrm{~dB}$ (dla częstotliwości $3 \mathrm{kHz}$ ). Najwyraźniejsza zmiana progu słyszenia dotyczy 3 $\mathrm{kHz}$. Wszystkie te wyniki nie wykazują jednak istotności statystycznej.

\begin{tabular}{|l|c|c|r|}
\hline & przed & po & $\begin{array}{r}\text { róż- } \\
\text { nica }\end{array}$ \\
\hline $125 \mathrm{~Hz}$ & 10 & 8,33 & 1,67 \\
\hline $250 \mathrm{~Hz}$ & 8,7 & 8,89 & $-0,19$ \\
\hline $500 \mathrm{~Hz}$ & 9,26 & 8,89 & 0,37 \\
\hline $750 \mathrm{~Hz}$ & 9,81 & 10 & $-0,19$ \\
\hline $1 \mathrm{kHz}$ & 7,59 & 6,11 & 1,48 \\
\hline $1,5 \mathrm{kHz}$ & 6,48 & 3,33 & 3,15 \\
\hline $2 \mathrm{kHz}$ & 8,15 & 5 & 3,15 \\
\hline $3 \mathrm{kHz}$ & 4,81 & 1,11 & 3,7 \\
\hline $4 \mathrm{kHz}$ & 3,15 & 2,22 & 0,93 \\
\hline $6 \mathrm{kHz}$ & $-0,19$ & $-2,22$ & 2,03 \\
\hline $8 \mathrm{kHz}$ & 1,11 & 0,56 & 0,55 \\
\hline
\end{tabular}

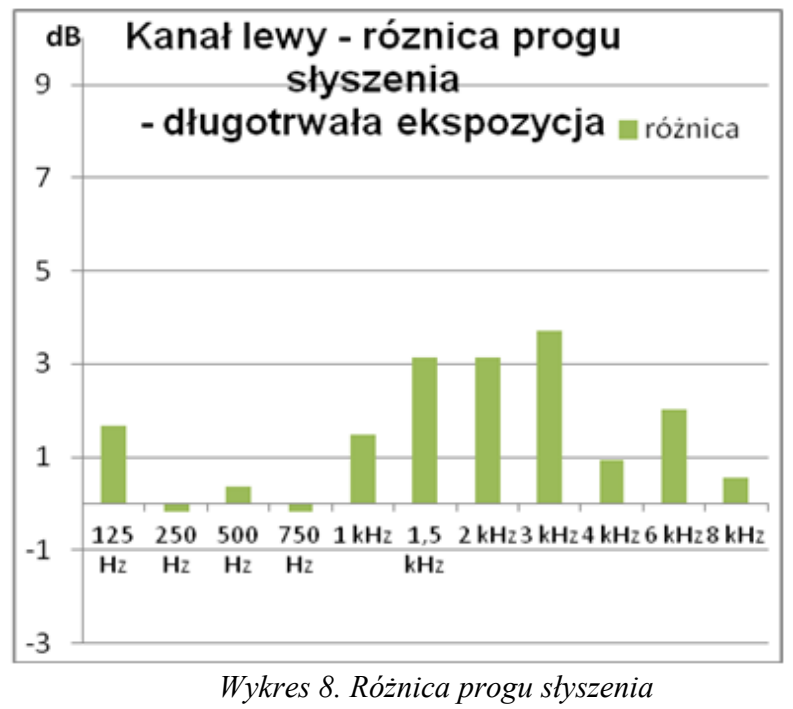

Lingwistyka Stosowana/ Applied Linguistics/ Angewandte Linguistik: www.ls.uw.edu.pl 


\section{Podsumowanie}

Wyniki badań audiometrycznych poddane analizie jakościowej i ilościowej pozwalają przyjąć te pomiary za badanie pilotażowe wskazujące tendencje, potencjalne hipotezy i kierunek dalszych badań. Wang et al. (2006: 256) wykazują w swoich badaniach, że leksykalne tony chińskie są inaczej przetwarzane przez rodzimych użytkowników języka chińskiego i przez użytkowników języków nietonalnych. Większa aktywność lewej półkuli charakteryzuje pierwszych, podczas gdy uczący się chińskiego nie dostrzegają tonalności jako cechy różnicującej leksykalnie. Ograniczone do pomiarów audiometrycznych wyniki tego badania, uzyskane na niewielkich grupach, są niejednoznaczne.

Dla grupy mniej zaawansowanej (A1+/A2), która była badana dwukrotnie, średni wynik progu słyszenia dla częstotliwości $250 \mathrm{~Hz}, 1 \mathrm{kHz}$ i $8 \mathrm{kHz}$ zmienił się dla kanału prawego o $3,93 \mathrm{~dB}, 5 \mathrm{~dB}^{4}$ i 4,29 dB. Wykazano bardzo wysoką istotność ${ }^{5}$ statystyczną dla $1 \mathrm{kHz}$ i zadowalająco dobrą dla $250 \mathrm{~Hz}$. Dla lewego kanału słuchowego dla częstotliwości 1,5 kHz, $2 \mathrm{kHz}, 6 \mathrm{kHz}$ i $8 \mathrm{kHz}$ zmiana osiągnęła wartości 3,57 dB, 3,58 dB, 7,5 $\mathrm{dB}$ i $4,28 \mathrm{~dB}$, przy dobrej istotności statystycznej dla $1,5 \mathrm{kHz}$ i bardzo wysokiej dla częstotliwości pozostałych.

Inaczej rzecz się ma dla niezależnych pomiarów grup o liczebności 24 i 9 osób. Wykazano zadowalającą istotność statystyczną wyników jedynie dla $3 \mathrm{kHz}$ i $6 \mathrm{kHz}$ kanału prawego (wartości średnie różnicy wrażliwości słuchowej - odpowiednio 3,89 dB i 4,45 dB). Pomiar wartości progowych dla lewego kanału słuchowego nie uzyskał wystarczająco wysokiego poziomu istotności $(\mathrm{p}<0,05)$ dla żadnej częstotliwości.

Podsumowując, wyniki tego badania wskazują na nieco wyższą wrażliwość słuchową prawego ucha osób polskojęzycznych znających język chiński biegle $(\mathrm{B} 2+/ \mathrm{C} 1)$ w porównaniu z nieznającymi chińskiego. Jednak osoby rozpoczynające naukę (poddane dwukrotnemu pomiarowi) wykazują na etapie poziomu A1+/A2 wyraźną (większą niż wyniki badania dwóch grup niezależnych) poprawę uwagi słuchowej, jeśli tak zinterpretujemy lepsze wyniki audiometrii tonalnej. Co ciekawe, wartości średniej różnicy zmiany wrażliwości słuchowej są lepsze dla ucha lewego. Wpisuje się to w interpretację Wanga et al. (2006: 250). Wskazują oni na znaczenie pozajęzykowych (akustycznych) cech dźwięku mowy przetwarzanych w prawej półkuli przez użytkowników języków nietonalnych uczących się języka tonalnego - chińskiego. Dalsze badania wpływu obcych dźwięków mowy na umysł mogą wnieść wiele w rozumienie procesów audytywnych i plastyczność mózgu wystawionego na stymulację dźwiękiem.

\section{Bibliografia}

Guo Jyun-Hong 郭俊弘 / Liu Huei-Mei 劉惠美 / Hung Kuei-Chun 黃桂君 /Wang HsiaoChuan 王小川 / Tsao Feng-Ming 曹峰銘 (2010), 修改語音基頻曲線與低通濾波 處理影響聽障學生國語聲調聽辨成效之研究, (w:), „特殊教育研究學刊”35(3), $77-101$.

\footnotetext{
${ }^{4} 5 \mathrm{~dB}$ jest wartością graniczną dla błędu pomiaru audiometrycznego, ale znaczącą jako wartość średnia.

${ }^{5}$ Za poziom istotności statystycznej przyjęto $\mathrm{p}<0,05$.
} 
Hojan, E./ E. Skrodzka (2005), Audiologiczne aspekty akustyki i psychoakustyki, (w:) M. Śliwińska-Kowalska (red.), Audiologia kliniczna. Łódź, 97-106.

Kratochvil, P. (1968), The Chinese language today. London.

Künstler, M.J. (2000), Języki chińskie, Warszawa.

Polański, K. (red.) (2003), Encyklopedia językoznawstwa ogólnego. Wrocław.

Sobol, E. (red.) (2006), Stownik języka polskiego.Warszawa.

Wang, Y./ A. Jongman / J.A. Sereno (2006), L2 Acquisition and Processing of Mandarin Tone, (w:) Li P./ L.H. Tan/ E. Bates/ O.J.L. Tzeng (red.), The Handbook of East Asian Psycholinguistics.Vol.1. Chinese, 250-256.

Whalen, D.H./ A.G. Levitt (1995), The universality of intrinsic F0 of vowels, (w:) Journal of Phonetics 23, 349-366.

Zajdler, E. (2010), Glottodydaktyka sinologiczna. Warszawa.

\section{Źródla internetowe}

URL http://laryngologia.pl/sites/19/ [Pobrano 23.03.2015].

URL http://www.staff.amu.edu.pl/ apraton/Jedrzej_Kocinski_pracownia_psychoakustyki_dla kognitywistow.pdf [Pobrano 9.04.2015].

URL http://livesound.pl/tutoriale/artykuly/4629-zrozumialosc-mowy [Pobrano 23.03.2015]. 